\title{
Challenges and Problems of Knowledge Management in Enterprises in Poland
}

\author{
Ryszard Borowiecki, Barbara Siuta-Tokarska \\ Cracow University of Economics, Cracow, Poland
}

\begin{abstract}
The aim of the publication is to show practical implications concerning knowledge management in enterprises on the grounds of the presented theoretical bases. The empirical part of the publication is to show relevant research concerning enterprises functioning in Poland, both in the small and medium-sized enterprises and the large enterprises. The first, theoretical part of the article systemizes the basic notions concerning the subject of the publication and referring to the question of knowledge and knowledge based management in an organization on the basis of Polish and foreign literature. In the second part, theoretical frames presented before are referred to the factual state, assessed on the basis of the research findings from the selected research centres. They concerned on the problems and the level of progress of Polish enterprises in knowledge management. Here, the analytical and synthetic approach was applied, followed by appropriate conclusions. The empirical part of the publication presents the main areas constituting the source of problems in the knowledge management process in Polish enterprises, as well as appropriate suggestions to counteract the low level of knowledge management in these entities. The paper takes into consideration the findings of empirical research in the selected research centres. On their basis, the condition of knowledge management in Polish enterprises was assessed. Moreover, appropriate conclusions and suggested solutions are presented.
\end{abstract}

Keywords: knowledge management, knowledge based economy, enterprises in Poland, large enterprise sector (LSE), small and medium-sized enterprise sector (SMEs)

\section{Understanding and the Substance of Knowledge}

\section{The Forms of Knowledge Classification}

In the most general terms, knowledge is a result of the act of cognition, however, the relation between knowledge and cognition has a character of mutual influence. On the one hand, knowledge is a consequence of cognition, on the other hand, cognition is conditioned by knowledge to a great extent (WielkaEncyklopedia, 2005). Undoubtedly however, the subject of knowledge is a specific individual, although the society is also indicated (WielkaEncyklopedia, 2005) ${ }^{1}$ as a significant source of both the past and the contemporary knowledge. Some authors also point at the biological sources of knowledge acknowledging that a certain store of knowledge used by an individual has an innate character.

Ryszard Borowiecki, Professor, Department of Economics and Enterprise Organization, Cracow University of Economics. Barbara Siuta-Tokarska, Ph.D., Department of Economics and Enterprise Organization, Cracow University of Economics.

Correspondence concerning this article should be addressed to Barbara Siuta-Tokarska, Department of Economics and Enterprise Organization, Cracow University of Economics, Rakowicka 27, 31-510 Cracow, Poland. E-mail: borowier@uek.krakow.pl; siutab@uek.krakow.pl.

${ }^{1}$ Knowledge gained socially is very often incoherent. 
It is worth noticing that "the possessed knowledge influences the choice of the explored subject and the way it is explored, whereas cognition gives a new store of knowledge, even the minimum one, which modifies the knowledge gained so far" (WielkaEncyklopedia, 2005). Such a modification may have both a quantitative ${ }^{2}$ and a qualitative ${ }^{3}$ character.

For the first time the notion of knowledge as "justified and true conviction” was introduced by Plato (Pawluczak, 2002). Then, Aristotle indicated specific kinds of knowledge (Kulczycki, 2012):

- knowledge which is universal and theoretical (Episteme);

- instrumental, contextual, and practical knowledge (Techne);

- normative knowledge based on experience, context, and common sense, defined as "practical wisdom" (Phronesis).

Within the theory of cognition, the combination of rationalism and empirism was suggested by Kant, who in turn, pointed out that any knowledge results from experience, but at the same time he acknowledged that experience should be supported by logical reasoning. In comparison with reasoning, basically boiled down to drawing conclusions from the possessed knowledge, experience is more diverse. It is divided into sensual experience, internal experience, so-called introspection or intuitive cognition, recognized as another type of experience or the third source of knowledge (alongside reasoning and experience) (WielkaEncyklopedia, 2005).

One of the classification forms are questions the possessed knowledge should give answers to (WielkaEncyklopedia, 2005).

- knowledge on specific, individual facts of historical or geographical type (what happened?);

- knowledge on various techniques, recipes and operating procedures (how to do something?);

- knowledge on regularities ruling the world: natural, social or psychological ones (why does it happen?);

- knowledge of a psychological type, enabling to distinguish various types of existences and phenomena (what is it?).

It should be emphasized that to a great extent individual memory, which is unreliable and limited, is the basis of the possessed knowledge. Therefore, it is supported by two other media, namely, the institutional media (e.g., specialists who may pass it to us) and the material media (e.g., books, computer memory), in case of which it is necessary to know the code in which knowledge has been recorded (language codes, maps, charts, drawings, metaphorical and analogous images are mainly used) (WielkaEncyklopedia, 2005).

Among the basic qualities which are desired for knowledge, the following should be indicated (Ziółkowski, 1989), usefulness dependent on the adopted axiology, ethos, lifestyle, etc., which is most frequently conditioned by the social environment, as well as its truthfulness, which in turn depends on the adopted criteria of truthfulness ${ }^{4}$. Among other qualities of contemporarily understood knowledge, the following are mentioned (Siuta-Tokarska, 2010): dominance, inexhaustibility, simultaneity, and non-linearity.

When analyzing the question of broadly-understood knowledge, we can indicate two fundamental problems related to it, expressed in the form of the questions (Scheler, 1990):

- To what extent the used knowledge is conscious knowledge and to what extent an unconscious part of knowledge may become conscious?

\footnotetext{
${ }^{2}$ When the previous state of knowledge is completed with new components.

${ }^{3}$ For example, when the previous knowledge turns out to be untrue or when the new elements of knowledge show that the structure of the previous knowledge is inadequate and it must be subject to structuring and ordering operations.

${ }^{4}$ Scientific criteria are a special case. As regards them, with reference to knowledge, justification is aimed at and it is done by the reference to transmission procedures, others, or, for example, most often occurring in the social practice reference to the authority of a person, an institution or a work.
} 
- To what extent individual knowledge is fully passed to others and to what extent it is possible to build a message from it which would fully pass the known knowledge to every person who knows the proper communication code?

Thus, nowadays, it is quite common to adopt a division of knowledge into two categories: codified (manifest, not hidden), that is organized, systematized, easy to measure, recorded knowledge which characterizes with a possibility to store and transfer in various ways, and not codified knowledge (silent, hidden, non-manifest), being a result of talent, experience, abilities, constituting a good of a special type, and because of that difficult to measure (Howitt, 1996). Generally, the literature of the subject indicates two basic dimensions of creating knowledge (Materska, 2006): the epistemological one, touching the sources of cognition (manifest/formal knowledge and hidden/silent knowledge) and the ontological one (relations between individual, group, organizational or inter-organizational knowledge).

When processing knowledge, we can indicate its four stages (Skyrme, 1999): during the first stage, data are distinguished, the data are the basic unit of information, the structuralized and interpreted set of information constitutes knowledge, and the ability to use, modify, and create knowledge is called wisdom.

On the present stage of social development, apart from the growing level of general knowledge, special attention is paid to knowledge related to the economic development, including knowledge which refers to the dynamically spreading technological progress. The progress is determined first of all by innovations based on new and constantly developed information and communication technologies, biotechnologies, the automation of production processes, the application of numerically controlled machines, etc.. The initiation and the proper use of the mentioned sources of technological progress in the economy of a given country decide about the innovativeness of this economy.

\section{Attributes of Using Knowledge in Organizations}

The knowledge stored and used is an exceptional attribute in the functioning of an organization, and it is a specific combination of ideas, institutions, the experience and the skills of people and their teams or groups. It is often reflected both in documents and in processes and procedures, practices and norms of the organization, and in the followed customs. It is particularly significant in organizations using the mass production of goods.

Knowledge gives an ability to solve problems on the basis of the possessed information, and the added value resulting from knowledge and knowledge management is "overcoming destructive impact of changeability and making out of it a chance for better work of the organization or customer service, or for the implementation of still another goal” (Materska, 2006). It also enables to predict, connect different facts, analyze and take decisions (Materska, 2006).

The commercialization of knowledge may undergo parallel in a codified form, namely, in the form of the sales of licences and patents and franchising, but also in the form of the expert knowledge, such as management contracts, consultations or counseling (Materska, 2006). It should be added that in the knowledge based economy, many organizations do not create knowledge, and their activities consist in its distribution and configuration (Fazlagić, 2003).

The theory of a knowledge based organization applies its division into: information or knowledge about facts, products and their properties, as well as know-how, that is procedural knowledge which is the ongoing description of the practices within the company, among others on how to organize the company, cash flow, how to establish functional divisions, etc. ("know-how is understanding of how to organize the company in 
accordance with the formal and informal divisions”) (Materska, 2006).

\section{Definitions of Knowledge Management in Organizations}

Knowledge management in an organization is understood as a process aiming at possibly best, optimal use of the resources of knowledge which is at the organization's disposal to achieve the desired effectiveness of activities, especially in the volatile and highly complex conditions of the environment.

Out of numerous definitions of knowledge management, we can indicate the following of its characteristics (Dąbrowski, Koładkiewicz, \& Staniewski, 2002):

- Knowledge management is a process owing to which organizations generate value from the intellectual assets and the knowledge based assets possessed by it (Santosus \& Surmacz, 2001);

- "Knowledge management is a process by means of which the organization generates wealth based on its intellectual assets or knowledge based organizational assets” (Bukowitz \& Williams, 1999);

- Knowledge management "is specific and systematic management of knowledge which is significant for the organization, and related to it processes of creating, gathering, arranging, diffusion, applications and exploitation, implemented in the strive for achieving the organization's goals” (Skyrme, 1999).

Although the problem of knowledge management is in the centre of attention of both contemporary theoreticians and practicians working for small and huge organizations, still it does not mean that the problem was not dealt with before or that it was dealt with too little.

\section{Knowledge Management in Organization-Theoretical Grasp}

\section{The Concepts of Knowledge Management in Organizations}

The knowledge management has been generally known for thousands years, which is proven by, among others, records coming from about 4,000 years ago and found in Syria, being the testimony that "the man gathered and distributed knowledge, tried to pass it from generation to generation, enabling development to new generations based on the achievements of the predecessors"(Kozarkiewicz-Chlebowska, 2012). The effects in the development of knowledge may be proved by the library in Alexandria, phonetic alphabet, papyrus, the invention of print, book and nowadays the Internet. The works of authorities from the field of management raise a lot of interest in the problem of knowledge in organizations, including the publications by Drucker from 1980s who popularized the notions like: knowledge based economy, leadership with regard to knowledge or knowledge as the most important, unique resource. Toffler and Nasbitt's works, published in the same period, played a similar role (Zarządzaniewiedza, 2000).

In consequence of analyzing the development of knowledge management concept in organizations, three basic approaches to this problems have been distinguished: the Japanese one, originating from the Japanese intellectual tradition and based on the division of knowledge (Nonaka \& Takeuchi, 2000); the resource one, based on the concept of key competences and key skills (Leonard-Barton, 1995); and the process one, comprising the processes of knowledge creation, codification, and transfer (Davenport \& Prusak, 1998).

The Japanese concept of knowledge management assumes that the conversion of knowledge occurs cyclically in the form of four processes, namely:

- Adaptation, consisting in permeating hidden knowledge into another hidden knowledge through learning by imitation and exercises;

- Internalization via the conversion of available knowledge into hidden knowledge as a result of learning in action; 
- Externalization through changing silent knowledge into manifest knowledge by using analogy, hypotheses, or even metaphors;

- Connection, consisting in the replacement of manifest knowledge into another one of the same kind as a result of ordering and the proper accumulation of various elements of available knowledge.

In the resource concept of knowledge management, the existence of five elements is distinguished, namely:

- Key skills including the knowledge and the skills of employees, and the management systems and techniques, as well as mandatory standards and values;

- Solving problems collectively and searching for the best solutions with the simultaneous sharing knowledge;

- Implementation and integration of new technologies and tools;

- Experimenting aiming at the search for better and innovative solutions;

- Importing knowledge.

The process concept includes its basic components, namely:

- Creating knowledge gained via its import from the environment, among others, as a result of taking over companies, or their best employees and the emergence of knowledge by creating favourable internal conditions;

- Codification of knowledge and its proper processing for its better understanding;

- Transfer of knowledge by transmitting it or presenting it to the recipient, and the absorption of the transmitted knowledge, that is its assimilation for further use.

The process concept was developed by Probst, Raub, and Romhardt (2002), in which they distinguished and analyzed six most important processes of knowledge management that are knowledge identification, knowledge acquisition, knowledge development, knowledge use, knowledge preservation, and knowledge distribution, which is presented in Figure 1.

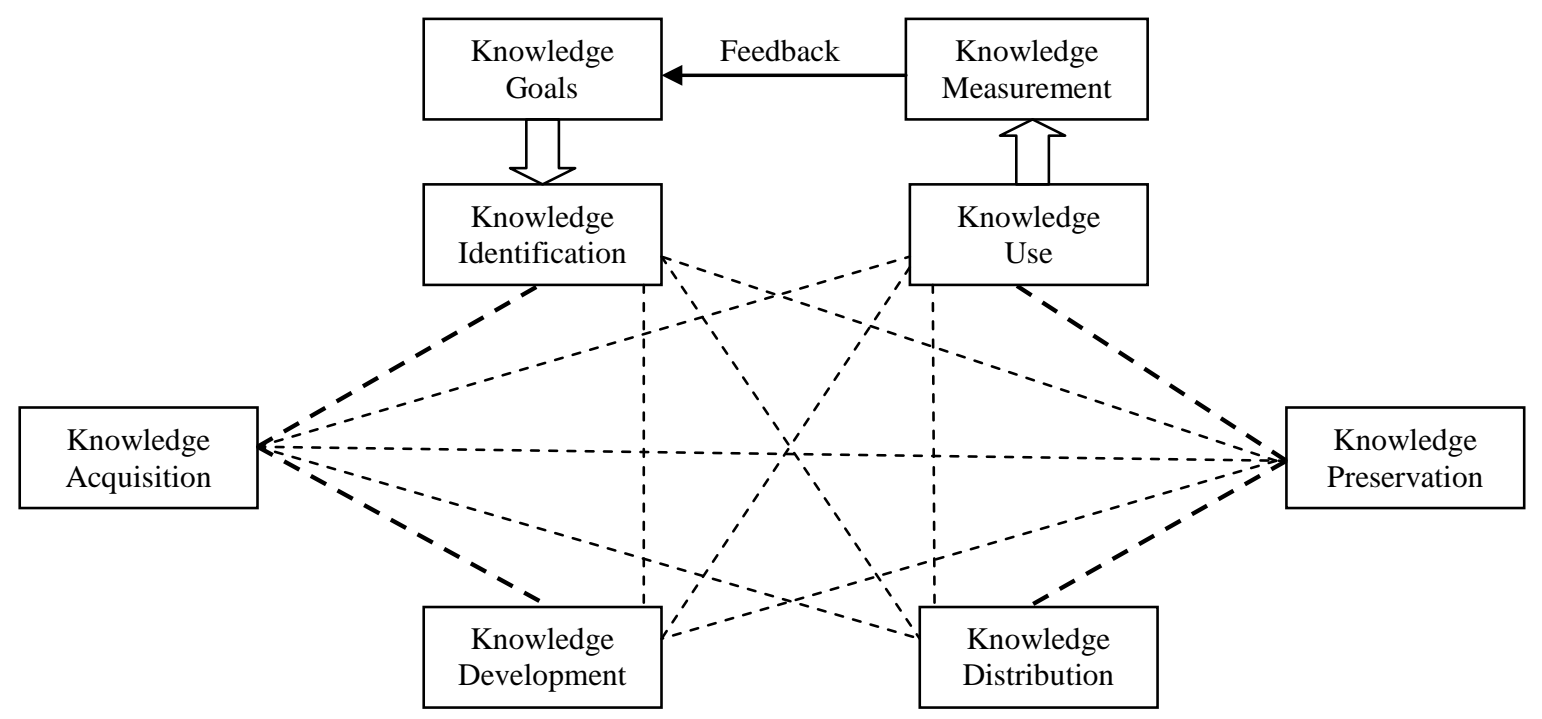

Figure 1. The elements of knowledge management.

The developed process concept in knowledge management as presented in Figure 1 is one of the most 
useful concepts for practical use in organizations, which does not prejudice the usefulness of using other concepts. Moreover, every organization, depending on the conditions of its functioning, can or even should apply an individual approach in knowledge management, with the proper use of the distinguished concept components. Knowing them may facilitate organizing the knowledge management in one's own organization.

\section{Factors Stimulating Modern Knowledge Management in an Organization}

Regardless of the above, we should bear in mind the necessity of flexible attitude in the concept of knowledge management in an organization in the practical grasp, adjusted to turbulent changes in the environment, also including the impact of the global economic crisis on enterprises. These fundamental changes in the environment require a change in the organizational form and structures, and the cooperation of organizations. In consequence, slimming and flattening of organizational structures take place, and at the same time there is an effort for organizational flexibility and the improvement in the adaptation ability to the competitive changes in global markets. It is believed that a flexible organization is the one whose structure and culture enables fast adaptation to the requirements of the competition and changing customer needs (Kochański, 2007).

At present, there is gradual withdrawal from the classic organizational structures based on the division of power and functions which are replaced by the structures based on projects, processes or cooperation networks (Kubicka, 2009). These types of the desired changes may undergo first of all in organizations based on knowledge management.

Similar claims are expressed by some economists (Sojka, 2007) presenting a view that in the digital era economy, enterprise competitiveness does not depend so much on their economic potential but rather on the ability to change fast and achieve the growing added value. Chances in this process are possessed mainly by organizations which are:

- based on knowledge;

- flexible and slim, among other things, able to invest fast, with low fixed costs;

- “intelligent”, having, among others, developed intellectual resources, investing in employees and research and development;

- inter-cooperative, searching for cooperation instead of competition and executing numerous contracts with clients and purchasers, as well as strategic alliances with competitors, among others in the form of cooperation in the legally legitimate form, e.g., in the form of so-called clusters of entrepreneurship.

Owing to the application of the knowledge management system in an organization, compared with the organization with the traditional management system, it is possible to achieve the following benefits, among others: improvement in communication, acceleration of the decision-making process, an increase in the organization innovativeness, shortening the time for solving difficult and key problems, broadening knowledge and employee competences, improving the effectiveness and the competitiveness of the organization operations on the market (Budziewicz-Guźlecka \& Drab-Kurowska, 2006).

\section{Knowledge Management in Enterprises in Poland—Empirical Research}

\section{Knowledge-Based Assets}

On the present stage of social and economic development of the world, special role falls on so-called Knowledge-Based Economy (KBE). The notion appeared as early as in 1990s (Fazlagić, 2003). According to Staniewski and Wawrzyniak (2003), the group of important actors building KBE includes: "the government 
and its departments, self-government authorities—regional and local ones, colleges and universities, as well as institutes and entrepreneurs”, but entrepreneurs are regarded the major actor building KBE.

It is extremely desirable for the Polish economy to make its way towards development in the direction of highly-developed countries, with reference to which we can talk about the real occurrence of KBM.

Due to the above, it seems justified to pay special attention to the development of Polish enterprises focused on knowledge management. In order to indicate and distinguish knowledge-based assets possible to be used in the knowledge management process in an enterprise, both on the tactic level and the strategic level. Figure 2 presents the knowledge management process according to Bukowitz and Williams (1999).

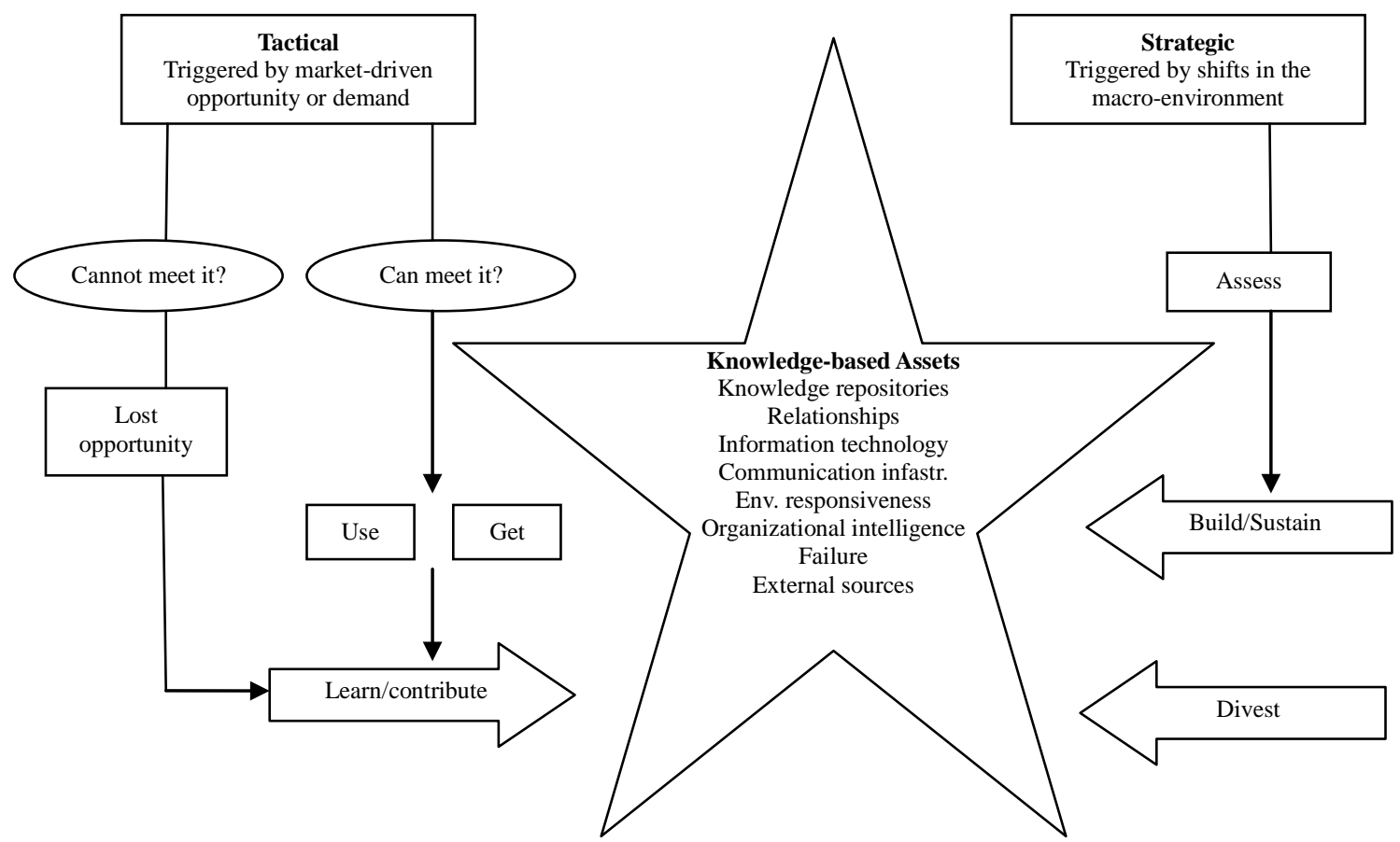

Figure 2. Knowledge management process according to Bukowitz and Williams (1999).

\section{Problems Related to Knowledge Management in Large Enterprises}

Enterprises in Poland which implement the knowledge management process encounter numerous problems and barriers which hinder their development. Figure 3 presents findings of the research conducted by Bernard Brunhes Polska (2004) ${ }^{5}$, within the framework of which 20 enterprises were studied, operating in such economic sectors as: the electric power industry, telecommunications, banking, trade, and IT.

Resulting from the data presented in Figure 3, the most important barriers hindering the functioning of the knowledge management system in enterprises in Poland include: remuneration system disregarding employees' efforts in gaining knowledge and sharing it, and insufficient motivation from the superiors to share knowledge, as well as the lack of time to pass one's knowledge to other employees.

\footnotetext{
${ }^{5}$ Bernard Brunhes Polska Spółka z o.o. w Warszawie. The research was conducted in 2004. The aim of the research was to diagnose enterprises at an angle of knowledge management methods and tools. Most frequently, senior executives, among others in human resources, finance, marketing or IT, were the respondents.
} 
[\%]

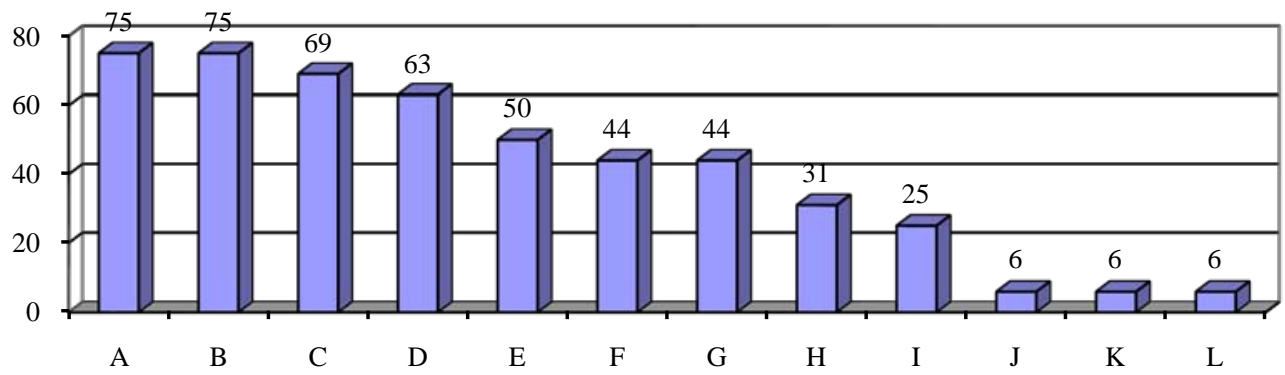

Figure 3. Barriers to knowledge management among the studied enterprises of electric power, telecommunication, banking and IT sectors in Poland (answers of some of the enterprises in which a given barrier occurs). Notes. Explanation: A-remuneration system which does not award employees for searching knowledge and sharing it, B-insufficient motivation from the superiors to share knowledge, C-lack of time to pass knowledge to others, D-lack of knowledge of employees on who possesses the information searched by them, E-the company structure promoting so-called silo effect (communication only within departments/sections), F-company culture not promoting the results of an individual and their knowledge on sharing experiences, G-limited funds for the implementation of new solutions, $\mathrm{H}$ - user-unfriendly IT system, I-the lack of employees' knowledge that their experiences may be useful to others, J-“hedge leveling” culture (disfavouring outstanding individuals by other employees), K—the "not invented here" syndrome (unwillingness to use solutions created somewhere else), and L-insufficient training of employees on the IT system operation.

What also results from the above research is that the knowledge management concept is known to these enterprises, and the companies taking part in the research notice the need to organize intellectual capital, but only some enterprises turn it into specific actions. Regardless of the fact that the contemporary, modern economy enforces the necessity and the skill to manage knowledge, as many as $75 \%$ of enterprises consider this area of their functioning as badly organized (Tomczak, 2005). Another implication of the research carried out by Bernard Brunhes Polska is that among the major factors motivating the studied entrepreneurs to manage knowledge, the following may be indicated: the development of employees' competences and the acceleration of operations, and only then an increase in the customer satisfaction and cost reduction.

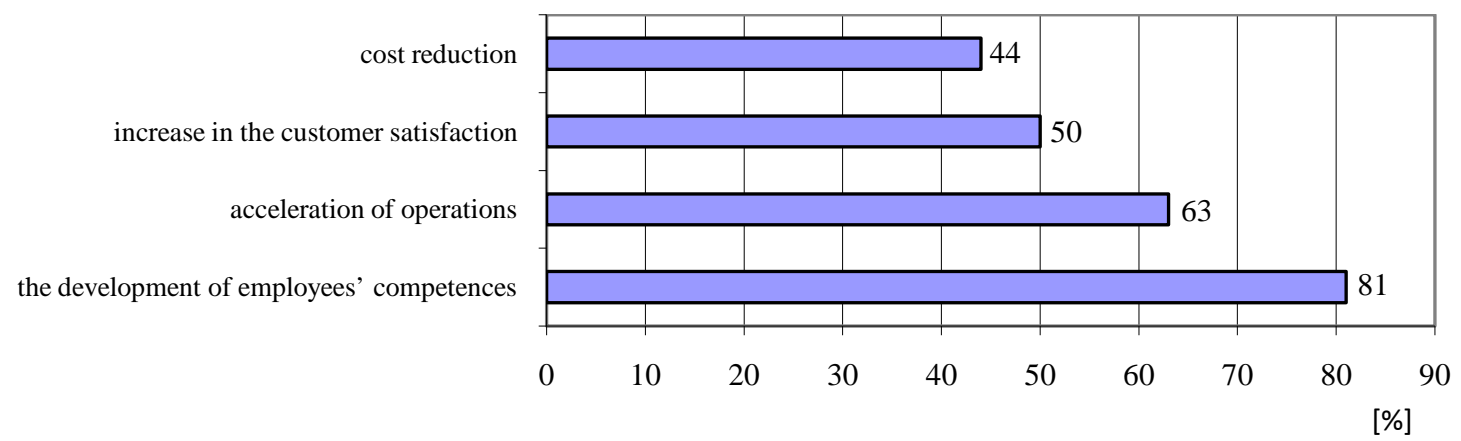

Figure 4. Major factors motivating entrepreneurs to manage knowledge in the company (the answers from a part of enterprises which mentioned a specific goal).

What results from the research ordered by KPMG Polska ${ }^{6}$ in $2004^{7}$, out of the 121 biggest enterprises,

\footnotetext{
${ }^{6}$ KPMG Sp. z o.o.-An audit, tax, and advisory company.

7 The research was ordered by KPMG and conducted by SMG/KRC Millward Brown Company on the representative sample of 121 large enterprises and organizations operating in Poland. The interviews were carried out by means of the CATI method-Computer-assisted telephone interviews. The respondents were presidents, CEOs, their deputies, and other executives, in consequence of which $80 \%$ of the respondents were members of management boards, responsible for making strategic decisions on the directions of development of the studied organization.
} 
employing at least 250 workers and making the revenues of over 40 million Euros per year, over $50 \%$ share of entities was marked in which the knowledge management process was not implemented and the need to implement it was not considered at all (28\%). In a relatively smaller part of the enterprises it was implemented or the implementation was in progress.

Considering the fact that large active enterprises in Poland, on the one hand, constituting small percentage of the total number of economic entities (namely, $0.16 \%$ of 1,704,527 enterprises in 2004), and on the other hand deciding about $42.3 \%$ of the people employed in enterprises in Poland (Borowiecki \& Siuta-Tokarska, 2008), and having considerable human, economic, and technical potential at their disposal, as well as a broad spectrum of capabilities to organize it properly and use it to introduce the knowledge management process, perform the implementation process within too limited scope and show too little interest in the implementation of knowledge management in the enterprise. Figure 5 presents detailed research findings on the course of the implementation process in large enterprises in Poland.

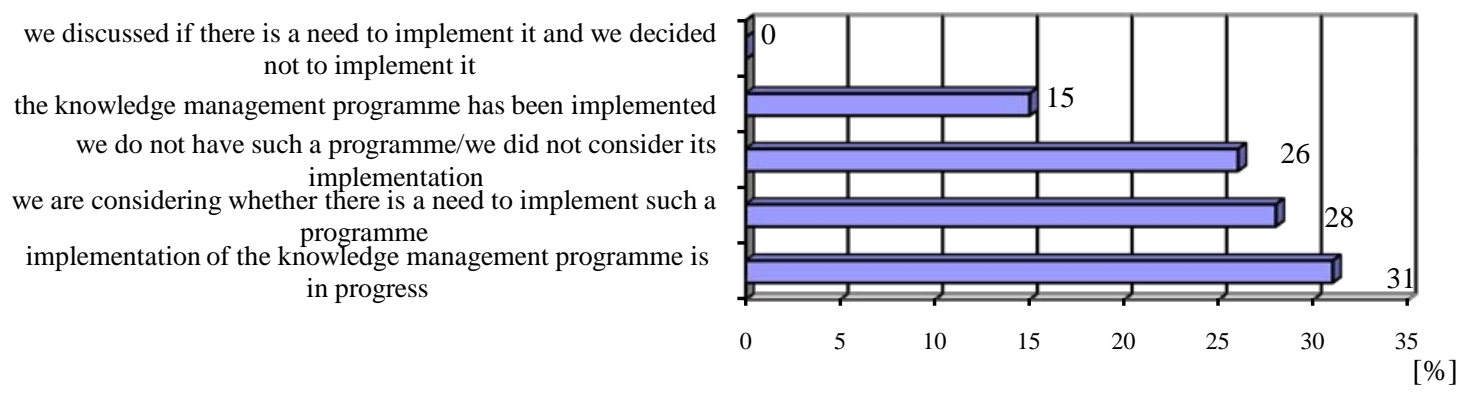

Figure 5. Large enterprises in Poland and the implementation of knowledge management (research ordered by KPMG, 2004).

Similarly to the presented Bernard Brunhes Polska research, also the research in large enterprises in Poland conducted on commission from KPMG Polska indicates specific problems related to knowledge management, out of which the lack of time to share knowledge was considered to be the most serious one (see Figure 6).

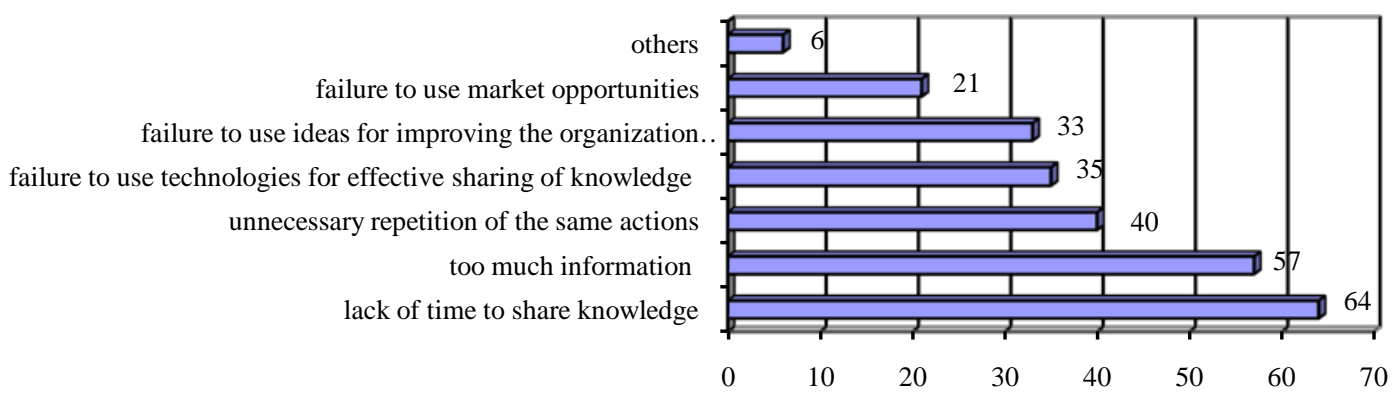

[\%]

Figure 6. Problems related to knowledge management in large enterprises in Poland.

The researchers found that in $18 \%$ of the surveyed enterprises the annual losses of the organization 
connected with an ineffective use of knowledge and intangible assets with reference to revenues constitute up to $5 \%$, whereas in $7 \%$ of the enterprises the declared range of losses was from $5 \%-10 \%$. In the overwhelming majority of the surveyed entities (65\%) it was difficult to assess what losses the enterprise makes on this account. We may assume that such an answer would be given by those enterprises in particular which do not implement the knowledge management process in their organization, and because of that they cannot determine consequences, that are losses related to an ineffective use of knowledge and intangible assets in their organization.

Moreover, the survey of large enterprises in Poland indicated that the implementation of knowledge management definitely took place by involving the members of the board and top executives (42\% and 21\% respectively) in it, and only in small percentage of entities by means of middle-level management employees and others ( $7 \%$ and $1 \%$ respectively). Comparing the results in this respect with international research-a different situation was observed in Poland in comparison with the situation revealed in highly-developed countries where a great majority of top executives postulated the implementation of the knowledge management system, and only then they were followed the members of the board. More detailed research into it could reveal the reasons for such a situation, with the simultaneous directing actions which are to lead to greater activation of top and middle-level management in large enterprises in Poland within this scope.

In order to determine the level of advancement in knowledge management in an organization, the Knowledge Management Journey Benchmark methodology may be used, within the framework of which the five-stage scale of knowledge management in an organization is used, from the stage of chaos to the stage of system integration, namely:

- The stage of chaos, in which the use of knowledge in practice is random and informal;

- The stage of awareness, characterizing with conducting pilot projects of knowledge management;

- The stage of focus in which there is a noticeable connection between procedures and tools used in knowledge management and benefits gained from it;

- The stage of management in which the knowledge management procedures and tools are implemented in the studied organization but certain technological and cultural problems still zero occur;

- The stage of system integration, in which knowledge management is an integral part of operating processes, and the resources of knowledge constitute a certain value in the organization.

As a result of the conducted research it was established that a great majority, $61 \%$ of the organizations in Poland, are on the lowest level of knowledge management, namely, they are knowledge chaotic, and none of them qualified to so-called stage of system integration. The detailed data within this scope are presented in Figure 7.

What arises from the KPMG research repeated in 2008 is that in large enterprises in Poland "there has been a set-back in the development of this management concept”, which cannot instill optimism (as many as 70\% Polish enterprises classify on the lowest level within the scope of using the resources of information and knowledge). According to Morawski, it may be the consequence of the lack of competences in the implementation of successive stages of knowledge management. In particular, it concerns the lack of "competencies to combine resources and skills resulting from information management, including the use of equipment, data base, programmes, networks, with the competencies of managing employees who create, acquire and use knowledge and information” (Wielicka, 2009). It is possible to agree with the opinion, all the more that as early as in 2008 (the period of the KPMG research) negative consequences of the global economic 
crisis manifested themselves also in the Polish economy and the effects related to it occurred with reference to enterprises in the form of special pressure on operating activity related to solving ongoing financial problems. Due to that, the operations of some enterprises were rather connected with the strategy of survival rather than the extension and development, including an increase in the expenditure on information and knowledge management.

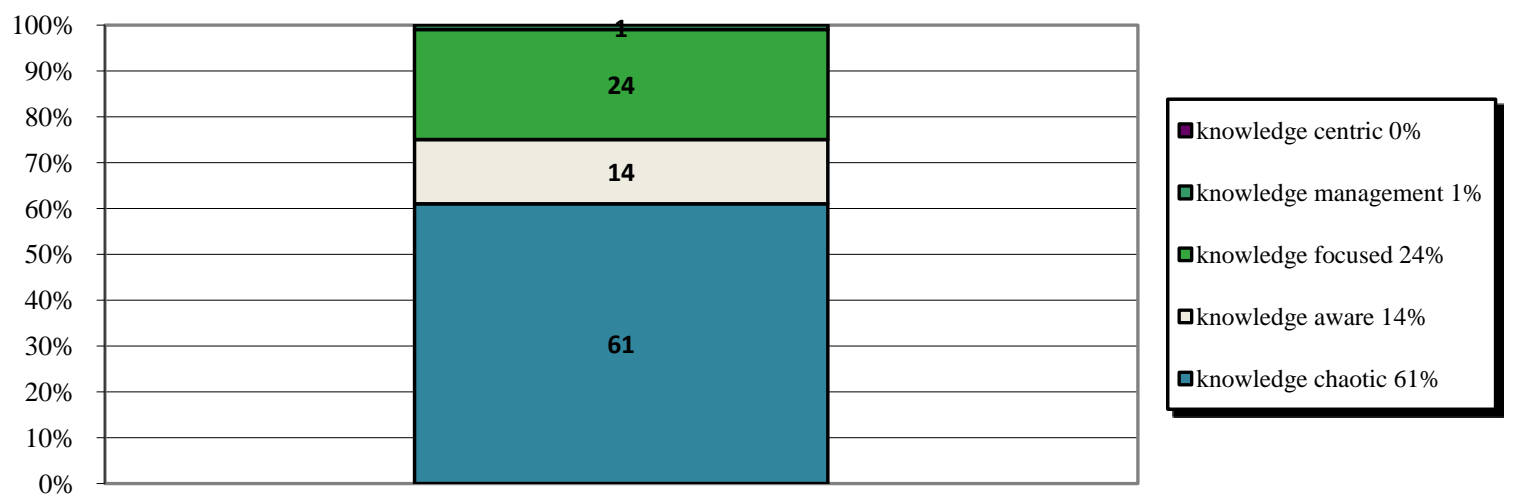

Figure 7. The findings of the research into the advancement of knowledge management in large organizations in Poland based on the five-stage scale of the assessment of the organizational development level.

\section{Problems Concerning Knowledge Management in Small- and Medium-Size Enterprises}

Some research concerning knowledge management in enterprises in Poland was also carried out with regard to the SME sector, which is micro, small and medium-sized enterprises employing from 0-249 employees in total, whose share in the total number of enterprises in Poland exceeds 99\%.

In the research conducted by the Central Statistical Office, it was marked that among the main sources of information for creating innovation in SMEs the following are used: internal sources-25\% of SMEs, clients-21\%, fairs and expositions- $12 \%$, competitors- $10 \%$, enterprises from the same group, conferences, meetings, professional journals-7\%, suppliers-5\%, patent disclosure, research and development units, consulting company-2\%, colleges and universities, academic institutions of the Polish Academy of Sciences, other Polish and foreign units-1\% of SMEs (Raport o staniesektora, 2010). The presented research findings confirm the low level of SME interest in acquiring information and knowledge which serves innovative actions, which should be assessed negatively. The CSO research also shows that in the SME sector, there is a group of enterprises which are really innovative, but these are mainly medium-sized entities, constituting a small percentage of the total number of enterprises of this class (Wolański, 2007).

What results from the research conducted by Krajowa Izba Gospodarcza Elektroniki i Telekomunikacji (KIGEIT) (National Economic Chamber of Electronics and Telecommunications) within the framework of the KIGEIT project is that small and medium-sized enterprises in Poland generally do not take advantage of the advanced IT tools to increase the quality and effectiveness of management, although in the prevalent number (90\%-93\%) they are equipped with computers and have the internet access. In practice, the majority of them use e-mail for business purposes and almost half of them have their own websites. However, computers are mainly used as typewrites, and the Internet is used to communicate or as a browser (Skibicka, 2010). It means that possessing the ICT tools mentioned above by small and medium-sized enterprises does not determine their 
comprehensive use, and only the performance of their basic functions (Skibicka, 2010).

What arises from the research conducted under the supervision of Professor Wielicki, California State University, on the sample of 1,100 enterprises of the SME sector in Poland, Portugal, and Spain, and 700 enterprises from California is that the awareness of Polish enterprises concerning benefits resulting from the use of IT tools in knowledge management is much lower than among American or West European entrepreneurs. The differences are also noticeable with reference to perceiving barriers in using professional applications in small- and medium-sized enterprises in individual countries with the indication to a greater awareness of Western entrepreneurs (Skibicka, 2010). Moreover, the conducted research shows that within the scope of equipping with computers and the Internet access, as well as the course of processes related to customer service and sales, there are significant similarities in the operations of SMEs in the distinguished countries. On the other hand, visible differences are observed in business processes related to production, logistics, trainings, and human resources management—but SMEs in Poland are placed on the lowest level in comparison with SMEs in the indicated countries.

From the analysis of the presented research we can draw a conclusion that the owners of small and medium-sized enterprises in Poland:

Rarely use modern ICT tools in company management, which is the consequence of the lack of awareness, and due to that of the lack of such needs, as well as of the financial barrier - high-tech tools are expensive, their implementation is also expensive. (Skibicka, 2010)

\section{Conclusions From the Research Into the Problem of Knowledge Management in Enterprises in Poland}

In the context of the presented outline of the situation within the scope of using high-tech ICT tools and the level of advancement of knowledge management in the SME sector in Poland, it seems justified to consider the suggestion of an appropriate educational and training programme for entrepreneurs, e.g., by specialist centres or agencies (advisory and training centres for SMEs, the National System of Services for small and medium-sized enterprises, Polish Agency for Enterprise Development, or others) alongside the presentation of appropriate empirical examples. Moreover, the suggestion by Skibicka (2010) seems worth considering, which concerns the creation of knowledge standards for small and medium-sized enterprises, related to the development of templates of necessary documents which could be adjusted by every company as required, as well as suggesting repetitive organizational solutions for a given type of enterprises, which, in consequence, could contribute to the improvement of knowledge management in their organizations. With reference to large enterprises, but also the SME sector, it seems advisable to introduce marketing activities properly publicized in the media (e.g., advertising) and suitable TV programmes of training and educational character, which would propagate the introduction of the knowledge management system in these entities, aiming at an increase in their competitiveness and motivating to the growth of pro-innovative activities. It may be performed, among others, by using appropriate structural funds, particularly taking into consideration the fact that the growth of competitiveness and innovativeness is currently one of the fundamental activities within the framework of the Europe 2020 strategy. 


\section{References}

Borowiecki, R., \& Siuta-Tokarska, B. (2008). Problemy funkcjonowania i rozwoju matych i średnich przedsiębiorstw w Polsce: Synteza badań i kierunki rozwoju. Warszawa: Difin.

Budziewicz-Guźlecka, A., \& Drab-Kurowska, A. (2006). Zarzqdzanie wiedza w dobie Nowej Gospodarki. Retrieved from http://www.instytut.info/IIIkonf/referaty/1c/Budziewicz.pdf

Bukowitz, W. R., \& Williams, R. L. (1999). The knowledge management field book. London: Financial Times Pretince Hall.

Davenport, T. H., \& Prusak, L. (1998). Working knowledge. Boston: Harvard Business School Press.

Dąbrowski, J., Koładkiewicz, I., \& Staniewski, M. W. (2002). Praktyki zarządzania wiedzą w przedsiębiorstwach funkcjonujących w Polsce. In R. Krupski, \& J. Lichtarski (Eds.), Stan i perspektywy rozwoju teorii i praktyki zarzqdzania na progu XXI wieku (pp. 513-528). Wrocław: Wydawnictwo AE im. Oskara Langego we Wrocławiu.

Departament Strategii Gospodarczej Ministerstwa Gospodarki. (2000). Zarzqdzanie wiedzq w społeczeństwie uczacym się. Warszawa, D.C.: OECD (Polishedition).

Fazlagić, A. (2003). Konstrukcja strategii dla przedsiębiorstwa opartego na wiedzy. In B. Wawrzyniak (Ed.), Zarzqdzanie wiedzq w przedsiębiorstwie (pp. 79-92). Warszawa: Wydawnictwo Wyższej Szkoły Przedsiębiorczości i Zarządzania im. Leona Koźmińskiego.

Howitt, P. (1996). On some problems in measuring knowledge based growth. In P. Howitt (Ed.), The implications of knowledge based growth for microeconomic Policy. Calgary: University of Calgary Press.

Kochański, T. (2007). Współcześni menadżerowie i przywódcy. In W. Kowalczewski, \& W. Matwiejczuk (Eds.), Kierunki i metody zarzadzania przedsiębiorstwem. Warszawa: Difin.

Kozarkiewicz-Chlebowska, A. (2012). Koncepcja zarzqdzania wiedzq-jej geneza, zastosowania i perspektywy. Kraków: Akademia Górniczo-Hutnicza Wydział $\quad$ Zarządzania. $\quad$ Retrieved from http://www.studenci.pl/zarzadzanie/metody/semeko_92.html

KPMG Polska. (2004). Zarzadzanie wiedza w Polsce 2004. Warszawa, D.C.: KPMG Polska.

Kubicka, J. (2009). Zmiany w zarządzaniu organizacją w gospodarce opartej na wiedzy. In T. Kupczyk (Ed.), Uwarunkowania sukcesów kadry kierowniczej w gospodarce opartej na wiedzy (pp. 80-97). Warszawa: Difin.

Kulczycki, E. (2012). Teoretyzowanie komunikacji (pp. 97-104). Poznań: Wydawnictwo Naukowe Instytutu Filozofii Uniwersytetu Adama Mickiewicza.

Leonard-Barton, D. (1995). Wellsprings of knowledge: Building and sustaining the sources of innovation. Boston: Harvard Business School Press.

Materska, K. (2006). Wiedza w organizacjach. Prologomena do zarządzania wiedzą. In B. Sosińska-Kalata, E. Chuchro, \& W. Daszewski (Eds.), Informacja w sieci. Warszawa:Wydawnictwo SBP. Retrieved from http://bbc.uw.edu.pl/Content/3/03.pdf

Nonaka, I., \& Takeuchi, H. (2000). Kreowanie wiedzy w organizacji. Warszawa: Poltext.

Pawluczak, A. (2002). Gospodarka oparta na wiedzy: Edukacja i infrastruktura informatyczna w Polsce i w wybranych krajach OECD. In K. Piech, \& G. Szczodrowski (Eds.), Przemiany i perspektywy polskiej gospodarki w procesie integracji z gospodarkq światowq. Warszawa: Instytut Wiedzy SG. Retrieved from http://www.instytut.info/images/stories/ksiazki_polecane/15_przemiany_i_perspektywy_przedsiebiorstw_1/r27.pdf

Polska Agencja Rozwoju Przedsiębiorczości. (2010). Raport o stanie sektora matych $i$ średnich przedsiębiorstw $w$ Polsce $w$ latach 2008-2009. Warszawa, D.C.: PolishAgency for Enterprise Development.

Probst, B., Raub, S., \& Romhardt, K. (2002). Zarzqdzanie wiedzq w organizacji. Kraków: Oficyna Ekonomiczna.

Raport o stanie sektora małych i średnich przedsiębiorstw w Polsce w latach 2008-2009. (2010). Warszawa: Polska Agencja Rozwoju Przedsiębiorczości.

Santosus, M., \& Surmacz, J. (2001). The ABC of knowledge management, CIO Magazine. Retrieved from http://www.cio.com Scheler, M. (1990). Problemy socjologii wiedzy. Warszawa: PWN.

Siuta-Tokarska, B. (2010). Zarządzanie wiedzą jako czynnik rozwoju współczesnej organizacji. In R. Borowiecki, \& J. Czekaj (Eds.), Zarzqdzanie zasobami informacyjnymi w warunkach nowej gospodarki (pp. 105-118). Warszawa: Difin.

Skibicka, B. (2010). Czy możliwe jest stworzenie standardów wiedzy dla małych i średnich przedsiębiorstw? Retrieved from http://www.pti.edu.pl/?q=standardy_wiedzy_dla_malych_i_srednich_przedsiebiorstw

Skyrme, D. J. (1999). Knowledge networking creating the collaborative enterprise. Oxford: Butterworth-Heinemann.

Sojka, L. (2007). Kvalitapracovnehożivota a suvistacekonstrukty. Presov: Fakulta Manażmentu Presovskej Univerzity, Acta Universitatis Presovensis. 
Staniewski, M., \& Wawrzyniak, B. (2003). Gospodarka oparta na wiedzy—Perspektywa przedsiębiorstwa. In A. Kukliński (Ed.), Gospodarka oparta na wiedzy: Perspektywy Banku Światowego (pp. 165-174). Warszawa: Komitet Badań Naukowych.

Tomczak, P. (2005). Jak polskie firmy zarzqdzaja wiedzq? Retrieved from http://www.e-mentor.edu.pl/artykul/index/numer/10/id/169

Wielicka, I. (2009). Rozmowa $z \quad d r$. hab. prof. Mieczysławem Morawskim. Retrieved from http://www.e-fakty.pl/index.php?option=com_content\&task=view\&id=5286\&Itemid=67

Wielka Encyklopedia PWN. (2005). Warszawa: Wydawnictwo Naukowe PWN S.A (pp. 196-197).

Wolański, R. (2007). Wiedza i innowacje $w$ matych i średnich przedsiębiorstwach-Postęp czy stagnacja. Retrieved from http://www.instytut.info/IIIkonf/referaty//1c/artykul\%20wiedza\%20inn\%20a\%20M\%8CP\%20R.Wola\%F1ski.pdf

Ziółkowski, M. (1989). Wiedza, jednostka, społeczeństwo: Zarys koncepcji socjologii wiedzy. Warszawa: PWN. 